\title{
Monetary policy, illiquid collateral and bank lending during the European sovereign debt crisis
}

\author{
Jean Barthélémy*, Vincent Bignon** and Benoît Nguyen***
}

\begin{abstract}
This paper assesses the effect on banks' lending activity of accepting illiquid collateral at the central bank refinancing facility in times of wholesale funding stress. We exploit original data on the loans granted by the 177 largest euro area banks between $2011 \mathrm{~m} 1$ and $2014 \mathrm{~m} 12$ and on the composition of their pool of collateral pledged with the Eurosystem. During this period, two-thirds of the banks in our sample experienced a sizable loss of wholesale funding. Panel regression estimates show that the banks that pledged more illiquid collateral with the Eurosystem reduced their lending to non-financial firms and households less: a one standard deviation increase in the volume of illiquid collateral pledged corresponded to a $1.1 \%$ increase in loans to the economy. This result holds for banks that were and were not run. Our finding thus suggests that the broad range of collateral eligible in the euro area may have helped to mitigate the credit crunch during the euro debt crisis.
\end{abstract}

JEL Classification: E52, E58, G01, G21

Keywords: collateral, loans, central bank, euro crisis

Reminder:

The opinions and analyses in this article

are those of the author(s)

and do not

necessarily reflect

their institution's

or Insee's views.
* Sciences Po and Banque de France (jean.barthelemy@sciencespo.fr).
* Banque de France and Université Paris Ouest (vincent.bignon@banque-france.fr).
${ }^{* * *}$ Banque de France and Université Paris 1 (benoit.nguyen@banque-france.fr).

This paper has previously been circulated with the title "Interbank Runs, Collateral Liquidity and Loan Supply: Evidence from the euro Crisis". For discussions and suggestions, we thank the editor and two referees, Régis Breton, Vincent Bouvatier, Douglas Diamond, Quoc Anh Do, Miguel Garcia-Posada, Florian Heider, Clemens Jobst, Tood Keister, François Koulischer, Antoine Martin, Jean-Stéphane Mésonnier, Imène Rahmouni-Rousseau, Miklos Vari, Xavier Vives, Vincent Sterk and Pierre-François Weber. We also thank, seminar participants in the Research Workshop of the Task Force on Banking Analysis for Monetary Policy of the MPC, Lisbon 2016, and in the conference on "Monetary policy and financial (in)stability". Paris 2016. We are especially grateful to Benjamin Pichot, Jocelyne Tanguy and Thierry Berthet for their expert help with the databases. The opinions expressed here are not necessarily those of the Banque de France or the Eurosystem. 
B anks extract profits from maturity and liquidity mismatches in their balance sheet: they fund long-term and illiquid claims on the asset side (e.g. loans), with shorter-term and more liquid debt on the liability side (e.g. interbank deposits) - see Kashyap et al. (2000) and Gorton and Winton (2003) for a survey. They face a risk that these resources are withdrawn before their asset side matures, which threatens their liquidity position. This situation is often referred to as a bank run. Bryant (1980) and Diamond and Dybvig (1983) formalize this risk, usually associated with the role of banks in transforming short-term liabilities into longer-term financing. It is well known since Thornton (1802) that in a situation of financial crisis, the appropriate response for a central bank is to increase its volume of refinancing. Bagehot (1873) added that this lending must be unlimited and guaranteed by collateral of good quality in normal time. Since Friedman and Schwartz (1961) and Bernanke (1983), it has been established that bank runs can evolve into a credit crunch, during which the aggregate balance sheet of banking sector shrinks and eventually contracts its supply of loans to the economy, thus depressing macroeconomic activity.

Fighting financial panics is a key role of central banks. The academic literature usually referred to this role as the lender of last resort function of central banks. The goal is to replace the lost funding of banks by central bank reserves in order to avoid the transmission of the financial stress created by illiquidity to other agents. Because the central bank needs to be protected against counterparty and credit risk, operations of lending of last resort are secured by collateral, which means that banks have to pledge eligible assets against the central bank refinancing. The range of eligible collateral varies considerably across time and central banks, and the Eurosystem ${ }^{1}$ accepts one of the broadest set of assets as collateral for its refinancing operations, from government bonds to credit claims.

There is some discrepancy between the understanding of lending of last resort tools in the academic debate and within central banks. Within the Eurosystem of central banks (or ECB as it is often inappropriately referred to), a first set of instruments labelled as lending of last resort instruments comprises the Marginal Lending Facility and the Emergency

1. The Eurosystem is composed of the European Central Bank (ECB) and the national central banks that implement monetary policy.
Liquidity Assistance ${ }^{2}$. Both are designed to fight a particular funding shock on a specific or restricted number of financial institutions. We do not deal with those instruments in this paper. We focus on the second set of instruments that central banks used as part of the implementation of their monetary policy and that is aimed at addressing the threat posed by systemic risk, and notably systemic bank runs, on macroeconomic outcomes. Some of those instruments are specifically designed to counteract a specific financial crisis and are usually grouped under the heading of "unconventional monetary policy tools" while others are part of the normal operational framework of central banks ${ }^{3}$. Both are aimed at fulfilling the mandate of the Eurosystem as defined by the Treaty of the Functioning of the EU, and hence are used to mitigate the threat posed by financial risk on the evolution of macroeconomic outcomes and notably the inflation rate. Unconventional tools have attracted a lot of attention, maybe to the detriment of the evaluation of how the operational framework can help to mitigate a financial crisis. We focus our paper on the contribution of a specific provision of the collateral framework of the Eurosystem and ask whether this provision may have contributed to smooth the consequences on credit supply of the European sovereign debt crisis.

The period of the sovereign debt crisis is well suited to inform on the impact of the central bank collateral framework on the economy. First, the period is characterized by a sharp reduction in money market funding and hence an increased reliance on central bank borrowing. The reduction in funding resulted in part from the reduction of the dollar funding of European banks by U.S. money market mutual funds (see Correa et al., 2013, and Ivashina et al., 2015). As we document in this paper, this run was also accompanied by a sharp reduction in euro-denominated wholesale funding, which was apparent in the reduction of the activity in the euro area interbank market. In our data at least some banks of

\footnotetext{
2. The main difference between the Emergency Liquidity Assistance (ELA) and the Marginal Lending Facility (MLF) is the determination of who is bearing the residual risk in case of default of the counterparty. Because the ELA aims to refinance solvent banks that face temporary liquidity problems outside of normal Eurosystem monetary policy operations, this assistance falls to the national central bank after the authorization of the governing council. Among other reasons, the ELA may be used to refinance banks constrained on the collateral defined in the general list of the Eurosystem.

3. This paper does not deal with many other crucial issues related to unconventional monetary policy measures undertaken during the crisis. Interested readers can refer to Claeys (2014) and Marx et al. (2016) for surveys.
} 
all countries were hit by a wholesale funding shock. Second, macroeconomic risk and the anticipation that some countries might have to exit the euro area reduced the market value of some European government bonds, which are the main source of liquid marketable assets in the euro area. The countries most hardly hit by the sovereign debt crisis are (with no particular order) Spain, Italy, Portugal, Greece and Ireland. Third, securitization - which can be used by banks to convert illiquid loans into more liquid asset-backed securities and covered bank bonds - was of little help during this period: the securitization activity was already small before 2007, and shrank further in the wake of the subprime crisis. All in all, wholesale funding stress increased the demand for central banks reserves and put pressure on collateral availability. The acceptance of illiquid collateral by the Eurosystem could thus have helped banks to sustain their lending activity or reduced the incentive to cut lending to the economy.

This paper studies the lending of last resort function of the Eurosystem in a time of bank funding stress, from the perspective of its collateral policy. We show that the collateral policy of the Eurosystem that allows banks to pledge credit claims of good quality as collateral boosted lending activity for banks that suffered and did not suffer a bank run during the euro debt crisis ${ }^{4}$. As documented in section 2, the ability to pledge credit claims is part of the regular operational framework of the Eurosystem since the creation of the Eurosystem and was only slightly modified with the crisis.

To show this result, we exploit three bank-level datasets at a monthly frequency. The first dataset reports all refinancing operations with the Eurosystem. The second dataset details the pool of collateral pledged by each bank as a guarantee for these refinancing operations. The third dataset reports the evolution of euro area banks' balance sheets. The final database consists of information on the 177 largest euro area banks at monthly frequency between January 2011 and December 2014. We construct a measure of interbank funding loss, and define a run variable at the bank level. For each bank, we also compute the volume of illiquid assets pledged with the Eurosystem as a share of its balance

4. In the rest of the paper, unless specified, we use non-marketable assets, credit claims, illiquid assets or loans interchangeably to describe the loan portfolio of a bank that is pledged or pledgeable as collateral with the central bank. We describe in details the operational framework and the properties of the eligible collateral in section 2. sheet. We interpret this share as a measure of a bank's ability to liquefy the most illiquid part of its balance sheet.

We estimate panel regressions in which the dependent variable is the lending activity to non-financial corporations and households, scaled by balance sheet size over the 2011-2014 period. We explain this variable by the intensity of the run that affected the bank, and by the total volume of collateral and the volume of illiquid collateral pledged. We crucially control for banks' specificities (capital ratio, ratings and bank fixed effects) and for common fluctuations of loans at the country level.

Our main result is that an increase in the share of illiquid assets pledged was associated with greater resilience of lending activity. More concretely, a one standard deviation increase in the volume of illiquid collateral pledged with the Eurosystem corresponded to a $1.1 \%$ increase in loans to the economy. This effect was due equally to a quantitative effect of collateral -an increase in the outstanding volume of collateral increased the supply of loans- and a composition effect - a shift from liquid to illiquid collateral was associated with an increase in loans for a given volume of collateral pledged with the central bank. This result, which also holds for banks that were run, is important as the transmission of monetary policy in the euro area relies mostly on bank lending, which represents an overwhelming share of non-financial firms' financing.

Our result also suggests that bank runs were associated with a reduction in loans. A one standard deviation increase in the intensity of the run led to a $0.9 \%$ drop in the loan supply. This drop was smaller for banks with a higher volume of collateral, irrespective of its liquidity class. Finally, we find that an increase in the equity ratio was associated with more loans.

Our paper is related to four parts of the literature. First, we investigate the impact of the degree of liquidity of the assets held by banks on the implementation of monetary policy. Kashyap and Stein (2000) have shown that banks holding less liquid assets tend to reduce their lending to the economy more when hit by an adverse funding shock (which they identify as an increase in the interest rate). As explained before this paper shows that the more illiquid the collateral banks can pledge with the central bank, the more resilient to bank runs lending activity is. Second, we contribute to 
the theoretical literature by providing empirical evidence on the instruments central banks can use to mitigate the real effect of bank runs, notably through the lender of last resort (see Diamond \& Dybvig, 1983; Diamond \& Rajan, 2005). Third, our paper contributes to the literature that shows that the technicalities of the implementation of monetary policy are keys in crisis time and specifically show that the type of collateral that a central bank must accept is not neutral (Bindseil \& Papadia, 2006; Bignon $\&$ Jobst, 2017). We emphasize the importance of the ability to pledge good quality but illiquid collateral. Fourth, we provide empirical evidence to support the theoretical argument according to which the central bank has a (very) long horizon because of its monopoly on the creation of reserves and banknotes. This allows the central bank to hold assets that the market would not be ready to hold, as argued by Bindseil (2014), Bindseil \& Jablecki (2013) and Bindseil (2013).

The rest of the paper is structured as follows. Firstly, we describe the collateral framework of the Eurosystem of central banks, and present the data. Then we discuss the empirical evidence on the runs on euro area banks and add further evidence on the quantitative importance of the loss of wholesale market funding by European banks for the period between 2011 and 2014 . Finally we present the main specification and our main results on the relation between collateral liquidity and the supply of bank loans.

\section{Eurosystem refinancing operations and collateral framework}

The Eurosystem issues central bank money and refinances the euro area banking system through regular "open market operations" (see Bindseil, 2014). They take the form of temporary loans of reserves against collateral. All credit institutions, defined as financial intermediaries that receive deposits and grant loans, are eligible if they fulfill the Basel capital ratio ${ }^{5}$. The Treaty on the Functioning of the European Union forbids the Eurosystem to discriminate against counterparties on the basis of their quality -for example the equity ratio- or business model.

The maturity of refinancing operations ranges from one week to four years. Before 2008,

5. Basel III capital requirements as defined in http://www.bis.org/publ/ bcbs189.htm regular operations were conducted every week and every month; their maturity was progressively extended with the unfolding of the crisis events to $3,6,12,36$ and finally 48 months and designated as longer-term refinancing operations (LTROs). The issue of the maturity must however not be overemphasized as banks can borrow unlimited amounts of reserves since October 2008.

To insure against counterparty default risk, the Eurosystem requires each borrower to pledge collateral. Since October 2008, the Eurosystem has been lending to credit institutions at a fixed interest rate and satisfies all bids submitted by banks. With this policy of fixed rate and full allotment and given the low interest rates, the implication is that the only relevant upper bound on the issuance of reserves is the total value of banks' eligible collateral.

Among central banks, the Eurosystem accepts one of the broadest range of assets as collateral (see ECB, 2013a and BIS, 2013) ${ }^{6}$. The set of eligible assets is larger than the set of collateral eligible with central clearing counterparties, the main operators of the private interbank market ${ }^{7}$. As part of the tools used to counteract the financial stress triggered by the failure of Lehman brothers in September 2008, the Eurosystem has expanded a number of times the list of assets eligible as collateral, but only one of those instances relates to the illiquid collateral (ECB, 2013b).

As a general rule, no asset with a default probability greater than $0.4 \%$ at a one-year horizon is eligible as collateral with the Eurosystem. Some securities are permanently accepted ("General framework"), while some other securities are accepted only temporarily ("Temporary framework"), as part of the measures taken by the Eurosystem to cope with the financial crises. The temporary list includes assets that have a default probability greater than $0.4 \%$ but lower than $1.5 \%$ at a one-year horizon. A single list of all the securities eligible as collateral for the whole of the euro area is published on the ECB's and national central banks' websites. The collateral is pledged at the desk of one of the national central banks. Although this makes a refinancing operation resemble a repurchase agreements (repo), it is

6. All the operational details described in this section have been in place from October 2008 to the date of the publication of this paper.

7. For example, Eurex CCP accepts a list of 11,000 eligible marketable securities (see Mancini et al., 2015) while the Eurosystem's single list of collateral comprises about 40,000 different marketable securities. 
more accurate to describe it as a collateralized loan, as the assets pledged are -apart from a few exceptions- generally not earmarked to a specific operation ${ }^{8}$. The assets are rather deposited in a pool to secure any of the potential operations of the bank with the Eurosystem. It is also noteworthy that ownership of the assets is transferred to the Eurosystem only in case of default.

The collateral framework of eligible assets comprises two categories: marketable assets assets that are traded in organized markets- and non-marketable assets -mostly credit claims such as mortgages and loans to non-financial companies of sufficiently low credit risk.

The marketable collateral consists of a set of between 35,000 to 45,000 unique securities identified by their International Securities Identification Number (ISIN). Eligible securities are classified into one of the five following categories. The first category consists of the most liquid assets: euro area government bonds, quasi-central banks reserves, i.e. fixed-term deposits (deposits of banks at the ECB, due to the early sterilization of the Securities Markets Programme) and cash. The second category comprises the bonds issued by supranational, public agencies, local and regional government, and "Jumbo" covered bonds with an outstanding amount greater than EUR 1 billion. The third category comprises covered bank bonds and corporate bonds, while the fourth consists of unsecured bank bonds. The fifth category comprises asset-backed securities. Any security must have a minimal rating of BBB- and must be issued in the European Economic Area.

The non-marketable collateral mainly comprises loans, referred as credit claims (CC). Credit claims have been accepted as collateral since the creation of the Eurosystem, but have been included in the general collateral framework with the introduction of the single (harmonized) list of collateral in 2007. A credit claim is eligible if it has a fixed and unconditional principal amount and if its interest rate is such that it prevents the occurrence of any negative cash flows (Tamura \& Tabakis, 2013). It is also required that the default probability of the loan is estimated to be lower than or equal to $0.4 \%$ in the Basel definition of a default probability.

8. The Banco de España still authorizes earmarking as an option (see Tamura \& Tabakis, 2013).
Only credit claims issued by euro area debtors are eligible.

The acceptance of a credit claim as collateral depends on the regulation defined at the euro area member state level, notably depending on the obligation or not to notify the debtor of the mobilization of its loan in the collateral pool (Sauerzopf, 2007). It also depends on the existence of a minimum threshold amount ${ }^{9}$. In December 2011, the ECB's Governing Council allowed national central banks to temporarily accept loans with the same characteristics as the loans acceptable in the General Framework but with a default probability between $0.4 \%$ and $1.5 \%$ (Bignon et al., 2016). This temporary extension is known as the "Additional credit claims" measure (ACC hereafter) and is reviewed every year by the Governing council of the Eurosystem. Eight national central banks participate in this programme (see ECB, 2012). Credit claims and additional credit claims (in value terms after haircut) amounted to a maximum of $27 \%$ of the total value after haircut of the collateral pool in $2012 q 4$ or 670 billion of Euro (see Figure I).

As long as there is a reliable market price, collateral is priced at market value, but in some cases - e.g. asset-backed securities- the Eurosystem operates its own model-based pricing capabilities (the "Common Eurosystem Pricing Hub"). Credit claims are valued at residual outstanding amount. A haircut is deduced from the market or model value or from the outstanding amount. As a general rule, the haircut is asset-specific and does not depend on the counterparty. It varies with the credit risk associated with the securities, as measured with the principle of first best rating (second best rating for ABS). Ratings can be taken from one or more authorized rating agencies and in some cases from ICAS (the Internal Credit Assessment System) ${ }^{10}$. The haircut also varies with the residual maturity of the asset (typically, the longer the residual maturity, the higher the haircut), with the liquidity risk (typically, the more illiquid the security is, the higher the haircut) and with coupon type. Table A-3 in Appendix details the valuation haircut grid used by the Eurosystem in the case of credit claims. By way of illustration, the haircut of certain credit claims can be as high as $65 \%$. The sum of all after-haircut value of the assets

\footnotetext{
9. EUR 500,000 is the minimum threshold for cross-border loans, while the minimum amount is at the discretion of each national central bank for other loans.

10. See for instance: $h$ ttps://www.ecb.europa.eu/paym/coll/risk/ecaf/html/ index.en.html.
} 
pledged by a counterparty defines the maximum amount of borrowing for a given bank with the Eurosystem.

It is noteworthy that on aggregate, there is no evidence of collateral scarcity during the period under study. The total outstanding amount of the eligible marketable securities (valued at market prices) increased from EUR 11 to 14 trillion from 2008 to 2014. This is more than ten times larger than the maximum of EUR 1 trillion in refinancing borrowed by banks.

However, the collateral constraint -defined as the ratio of the reserves borrowed to the value of the pool of collateral after haircuts- may have been binding at the bank level. In June 2012, at the onset of the crisis, $11 \%$ of the banks in our database had a utilization rate of their collateral pool greater than $90 \%$, while $20 \%$ had a utilization rate greater than $80 \%$. These levels are especially high if one remembers that the collateral pool is also used to secure the intraday payments made by banks using the Eurosystem-operated payment system that is known as Target 2. A bank can thus be collateral-constrained for its refinancing operations well below the $100 \%$ threshold. Moreover, eligibility criteria may matter even for banks that are over-collateralized. The eligibility of certain assets as collateral is likely to impact their relative degree of liquidity compared with non-eligible assets and hence to alter the incentive to hold them.

\section{Data and construction of variables}

We construct and merge three databases at the bank level. The first database reports the evolution of banks' balance sheets. The second provides the composition of the collateral pool pledged by each bank with the Eurosystem. The third gives the volume of refinancing operations of each bank with the Eurosystem.

Presentation of the databases. The first database is the Individual Balance Sheet Items dataset (IBSI), which includes data on the balance sheets of the 255 biggest banks in the euro area since 2007 at a monthly frequency. It is compiled by the ECB and national central banks, and is made available to Eurosystem researchers on a confidential basis. The sample of reporting banks has been chosen to include the 150 largest euro area banks by total assets, to reflect the representativeness of the euro area countries' banking systems and to reflect banks'

\section{Figure I}

Collateral pledged with the Eurosystem since 2004 after valuation and haircut

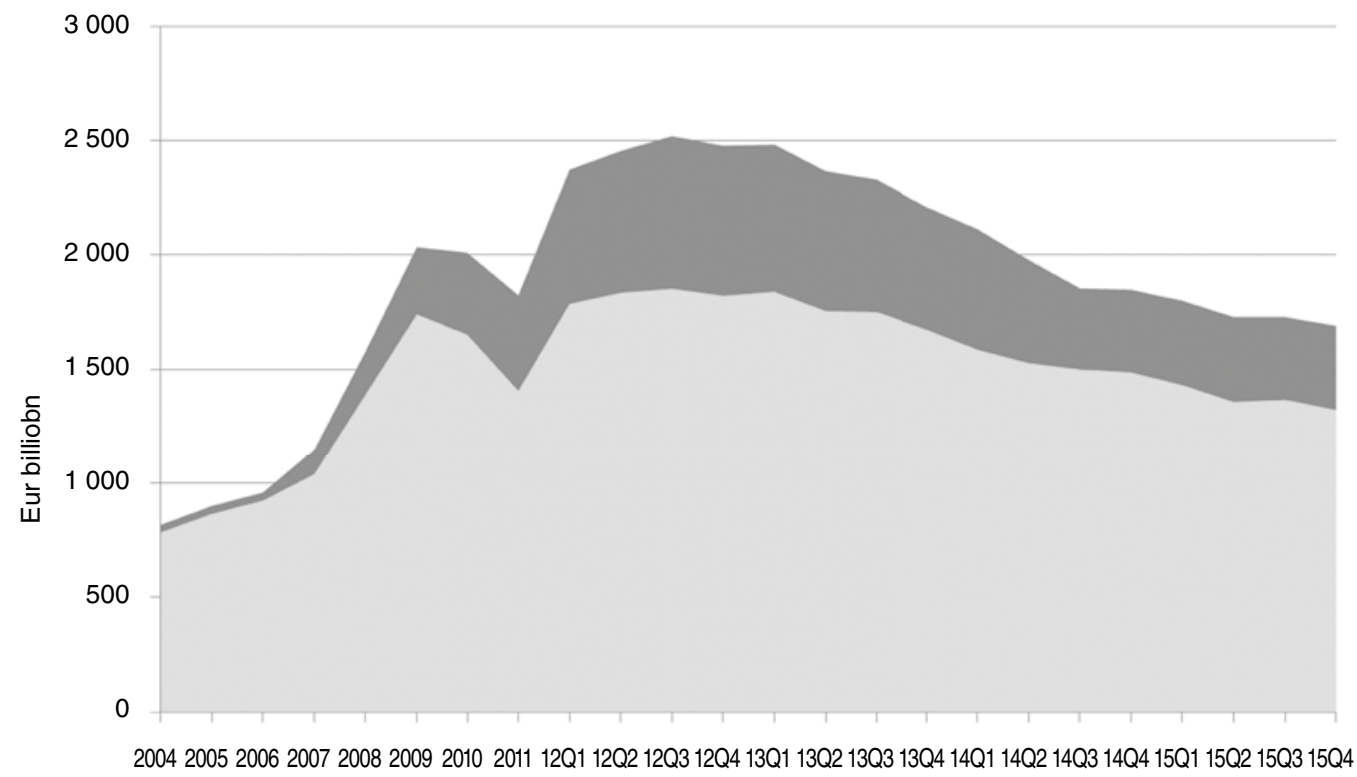

Marketable $\quad$ Non-marketable

Coverage: All banks that have maintained a collateral pool with one central bank of the Eurosystem.

Source: Authors' computations using Eurosystem data on collateral pledged with the Eurosystem by the euro-area banking system. 
participation in refinancing operations and the diversity of their business models. The banks in the IBSI dataset account for almost $70 \%$ of both the total main assets of the euro area banking sector and the total credit supply to euro area residents, as shown in Table 2.

We clean the database for mergers and acquisitions. To this end, we first search for large abnormal changes in the size of banks' balance sheets. When we are unable to find any meaningful explanation for this change using publicly available information, we drop the bank. When this abnormal change corresponds to the month of a bank merger or acquisition, we split the series into two parts to build a pre-merger and a post-merger series. We choose to clearly identify a merger to allow the new and the old entities to display possibly different characteristics. We also drop banks that do not lend to households or non-financial corporations, and exclude banks that never borrow either in the interbank market or from the Eurosystem, i.e. banks that are unconcerned about posting collateral $^{11}$. In the end, our final database consists of 177 banks. This is equivalent to the number of banks included in other papers using IBSI

11. This feature is rare and signals a specific business model that is not comparable to other banks. data (see for instance de Haan et al., 2015). The 177 banks represent half of the banking activity of the euro area (see Table 2).

The second database provides the composition of the collateral pool pledged by banks with one of the Eurosystem national central banks from January 2011 to December 2014. This proprietary database is typically used for operational purposes in the implementation of monetary policy refinancing operations. On average, 1,650 banks have maintained a collateral pool with the Eurosystem, with a minimum of 500 banks and a maximum number of 1,850 banks. The dataset comprises the composition of each pool at the security or loan level. The database comprises $8,174,320$ observations of pledged credit claims, i.e. an average of 50,603 loans per bank and month. We use this database to extract information at the monthly frequency on the total value of the collateral pool after haircut and on the total value after haircut of credit claims pledged by each bank.

The third proprietary database reports each refinancing operation made by individual banks with the Eurosystem, from the 1-week horizon in the context of the Main Refinancing Operations (MROs) to the Long-Term Refinancing Operations (LTROs), which have a 1-month

Table 1

Banks' balance sheets in the Individual Balance Sheet Items database

\begin{tabular}{|l|c|}
\hline \multicolumn{1}{|c|}{ Assets } & Liabilities \\
\hline Loans to households $(\mathrm{HH})$ & Capital and reserves \\
Loans to non-financial corporations (NFC) & Debt \\
Loans to monetary and financial institutions (MFI) & Deposits HH \\
Loans to government & Deposits NFC \\
& Deposits MFI \\
Bonds (government and corporate) & \\
Stocks & \\
External assets & External Liabilities \\
\hline
\end{tabular}

Table 2

Coverage of the Individual Balance Sheet Items sample, as of end-2014m12

\begin{tabular}{|l|c|c|c|c|}
\hline & EA & IBSI sample & Final sample & $\begin{array}{c}\text { Coverage } \\
\text { (Final/EA) }\end{array}$ \\
\hline $\begin{array}{l}\text { Number of monetary } \\
\text { and financial institutions (MFI) }\end{array}$ & & 255 & 177 & \\
Total assets (Eur bn) & 27,825 & 19,010 & 15,084 & $54 \%$ \\
Total loans (Eur bn) & 17,094 & 11,789 & 9,175 & $54 \%$ \\
\hline
\end{tabular}

Source: ECB Individual Balance Sheet Items monthly report. 
to 4-year horizon ${ }^{12}$. We construct a monthly series of the stock of refinancing of each bank, taking into account that some of these operations were repaid early. On average, 524 banks participated in the refinancing operations each month, with a minimum of 144 banks and a maximum of 997 banks a given month.

Merging these three databases gives a population of 177 banks at the monthly frequency between January 2011 and December 2014. Banks are not necessary present all the time in the sample and we run our regressions on 8221 observations ${ }^{13}$.

Construction of the variables. We construct, for each bank at each date, the following variables. First, we construct the stock of loans to the economy as a share of the total bank balance sheet one period before. We label this variable Loans while the total of the balance sheet is labelled as Assets. It includes both loans to households and to non-financial corporations, but we exclude loans to other monetary and financial institutions to avoid capturing a feedback loop between banks. The latter is reported under the Interbank lending heading.

Then, we construct the share of illiquid collateral pledged by each bank with the Eurosystem by computing the ratio of the value after haircut of all credit claims pledged with the Eurosystem scaled by the size of the bank balance sheet one period ahead. For each bank, we use the end-of- month value of credit claims and additional credit claims. We label this variable Illiq collat. Similarly, we compute Liq collat, the share of liquid collateral, defined as government and corporate bonds. The sum of these two ratios is Illiq + Liq collat.

Finally, we construct a measure of the reliance of each bank on wholesale funding. We label this variable Interbank Because the refinancing of the Eurosystem is recorded under the heading deposits from MFI, we subtract from the variable Deposits $M F I$ on the liability side of a bank's balance sheet the stock of the bank's refinancing with the Eurosystem. The reason is that from an accounting point

12. LTROs comprise also: TLTRO, targeted long-term refinancing operations through which banks can borrow only if they achieved a certain target of lending and VLTRO, very long term refinancing operations that are unconditional to the use of the refinancing.

13. 3,559 observations of banks never run $+4,840$ observations of banks run at least once at the monthly frequency (see tables 3 and 4) -177 observations $=8,222$ (as we run regression with a right-hand side lagged-value variable) and one bank has missing values missing during one month. of view, a central bank is a bank, and hence the borrowing from it is part of Deposits MFI item. To properly measure the funding loss from the interbank market, we therefore construct a measure of interbank funding net of central bank refinancing. Another item of wholesale funding external to the euro area (and hence including from the US money market mutual funds) is accounted for under the heading External Liabilities. By adding these two items, we obtain a measure of gross wholesale funding for each bank. In the rest of the paper, we label this variable -with a slight abuse of language- Interbank borrowing. We use gross wholesale funding to construct a measure of the bank run that we define in the next section. Finally, we also measure net exposure to wholesale funding by subtracting the amount of interbank lending on the asset side of the bank's balance sheet to obtain the Net interbank position.

\section{Bank financing and the run on European banks}

Banks are traditionally reliant on short-term funding sources such as interbank loans or money market mutual funds deposits ${ }^{14}$. Market funding can be either unsecured or secured with collateral (repos), but the unsecured segment almost disappeared in the euro area with the subprime crisis in $2007^{15}$. This paper studies the aggregate volume of interbank and money market funding rather than studying a specific money market instrument. This allows us to take into account both the European banks' borrowing from U.S. money market mutual funds and total European -mostly secured- interbank lending. The drying-up of the external short-term funding of euro area banks from U.S. money market mutual funds (MMFs hereafter) has been documented by Correa et al. (2013), Chernenko and Sunderam (2014) and Ivashina et al. (2015). Mancini et al. (2015) have documented the partial substitution between unsecured and secured money market funding by European banks. Pérignon et al. (2017) focus on wholesale funding raised through certificates of deposit since 2007, showing that the aggregate volume did not vary significantly and that some banks suffered from a sharp reduction

14. See for example Chapter 3, "Changes in bank funding patterns and financial stability risks", of the 2013 IMF Global Financial Stability Report, pp. 105-148.

15. The various issues of the ECB's yearly money market survey document the sharp reduction in funding on the unsecured segment of the interbank market, starting with the subprime crisis in 2007. 
while other did not. By focusing on an aggregate measure of wholesale funding, we therefore avoid the difficulties associated with the treatment of the substitution across different short-term funding sources.

There are two narratives of the euro debt crisis in terms of what caused the drying-up of banks' wholesale funding. Some papers describe the euro crisis as a run on banks caused by their holdings of too much (risky) domestic sovereign debt (see for example Acharya \& Steffen, 2015). Others emphasize the macroeconomic origin of the crisis: The expectations of the breakup of the euro area triggered a sharp reduction in cross-border wholesale funding, for fear of counterparty risk. We do not take a position in this debate but instead construct two types of measures of the euro area wholesale funding run that may reflect either one or the other potential causes of runs. We first compute the average funding loss of banks and describe the construction of the variables.

Measuring the run. We construct a measure of the loss of wholesale funding by defining a run in terms of two aspects. The first aspect is a duration variable measuring the time during which a bank suffered from a reduction in wholesale funding. The second aspect is a variable measuring the size of the run. We multiply the duration variable by the size variable to obtain the Run variable. The duration variable is a dummy that is set equal to 0 during the period in which the bank had a stable interbank funding. For a bank, a run starts if its Interbank funding variable decreases by at least $10 \%$ on a month-on-month basis over the 2010m1-2014m12 period $^{16}$.

For any bank that has breached the $10 \%$ funding loss, we then run a break test in level of one unknown break to decide the date of the end of a run. We set equal to 1 the duration variable in all months between these two dates. Otherwise, we set it equal to 0 .

The size variable measures the size of the run suffered by the bank. The loss is measured as a cumulative loss of wholesale funding computed as the percentage change in wholesale funding between the first and the last month of the run as a percentage of total assets at the bank level.

16. We have checked that all $10 \%$ drops in our sample -when they occur- are greater than one standard deviation of the month-on-month changes in interbank funding.
More precisely:

$$
\text { size }=\frac{\text { Interbank }^{\text {last }}}{\text { Assets }^{\text {last }}}-\frac{\text { Interbank }^{\text {start }}}{\text { Assets }^{\text {start }}}
$$

where the subscript start (last) indicates the first (last) month of the run. The Interbank and Assets variables denote the amount of wholesale funding and the total assets of the balance sheet of a bank respectively.

Figure II plots the number of banks that were run according to our definition of a run. It shows that a maximum of 77 banks were simultaneously run during the summer of 2011, among the 177 banks of our sample. We also overlaid a measure of interbank market stress, the "BOR-OIS" spread between unsecured 3-month interbank loan (Euribor 3-month) and the same tenor overnight-indexed swap (OIS) in which the principal is never exchanged and thus considered as almost risk-free rate. Interestingly, our measure on the number of bank runs increases continuously and reaches its maximum before the greatest peak of the interbank market stress measure of the Fall of 2011, suggesting that the aggregate outcome in terms of interbank stress is preceded by individual difficulties in the wholesale funding market.

We exploit the IBSI database to describe the main differences between the banks that were run and those that were not. More precisely, Tables 3 and 4 give the average value of the main balance sheet items for banks never run, and the same statistics for banks run at least once over the $2011 \mathrm{~m} 1-2014 \mathrm{~m} 12$ period. The "Run" variable shows that the 102 bank runs correspond to an average wholesale funding loss equivalent to $6 \%$ of the bank's total liabilities. At the $95 \%$ percentile, this average loss amounts to $19 \%$.

The banks that were run do not seem to differ otherwise on average from the banks that are not run, based on their balance sheet composition. The share of lending to the economy over total assets is $54 \%$ vs. $53 \%$ respectively. Similarly, the share of interbank lending to the other banks -with $14 \%$ vs. $17 \%$ respectively- or the share of securities held -with $17 \% v s .15 \%$ respectively-are identical for the two groups of banks. On the liabilities side, the equity capital and the debt issued by the two types of banks stand at similar levels, although the capital ratio of banks that are run is slightly higher -at $8 \% v s$. $7 \%$ for banks that are not run. The banks run do not differ in terms of the share of long-term debt (bonds) as a percentage of their total liabilities 
Figure II

Total number of banks and of banks run Jan 2010 - Dec 2014

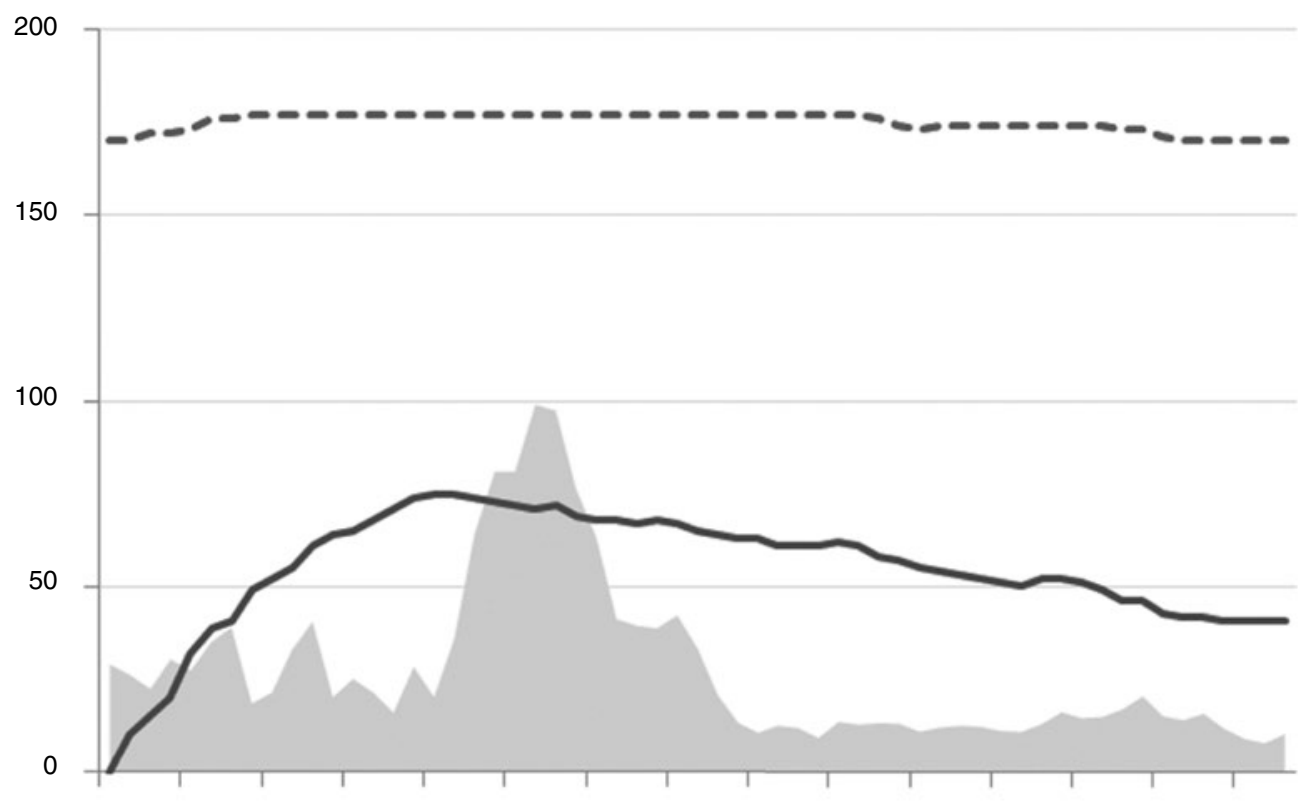

Feb-10 Jun-10 Oct-10 Feb-11 Jun-11 Oct-11 Feb-12 Jun-12 Oct-12 Feb-13 Jun-13 Oct-13 Feb-14 Jun-14 Oct-14

\begin{tabular}{|c|c|}
\hline & Euro BOR OIS 3-month (bps) \\
\hline 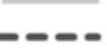 & Number of banks \\
\hline 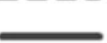 & Number of banks run \\
\hline
\end{tabular}

Note: For the exact definition of the run, see the text.

Coverage: 177 banks from the IBSI database of the Eurosystem, see table 1 and text for details.

Source: Authors computation using the IBSI data on euro-area banks' balance sheet, see text for formulas.

Table 3

Summary statistics, banks never run (2011m1-2014m12)

\begin{tabular}{|l|c|c|c|c|c|}
\hline Variable & Obs. & Mean & Std. Dev. & P5 & P95 \\
\hline Run & 3,559 & 0 & 0 & 0 & 0 \\
Illiq collat & 3,559 & .8 & 1.6 & 0 & 3.1 \\
Liq collat & 3,559 & 4.1 & 5.4 & 0 & 14.1 \\
Tot collat & 3,559 & 4.9 & 5.8 & 0 & 15.2 \\
Bonds held & 3,455 & 15.4 & 9.5 & 1.1 & 31.7 \\
Loans & 3,559 & 53.1 & 21.1 & 10.4 & 82.2 \\
Debt issued & 3,559 & 15.3 & 17.7 & 0 & 44.2 \\
Interbank lending & 3,559 & 17.7 & 15.8 & 1.9 & 48.4 \\
Interbank borrowing & 3,559 & 28.6 & 22.4 & 3.6 & 79.3 \\
Net interbank position & 3,559 & -11 & 21.6 & -54.3 & 22.3 \\
CB refinancing & 3,559 & 1.8 & 3.8 & 0 & 11.3 \\
Capital ratio & 3,559 & 8 & 4.2 & 2.5 & 14.7 \\
\hline Rating & 1,944 & 5.8 & 2.9 & 1 & 12 \\
\hline
\end{tabular}

Note: All variables as a \% of total assets except Rating for which 1=AAA and an increment of 1 corresponds to one notch.

Reading: Among banks that never experienced a run during our period under review, the mean of bonds held normalized by the total asset was

$15.4 \%$ between $2011 \mathrm{~m} 1$ and $2014 \mathrm{~m} 12$.

Source: IBSI database, Banque de France and authors' computations. 
Table 4

Summary statistics, banks run at least once (2011m1-2014m12)

\begin{tabular}{|c|c|c|c|c|c|}
\hline Variable & Obs. & Mean & Std. Dev. & P5 & P95 \\
\hline Run & 4,840 & 5.4 & 8.9 & 0 & 20.3 \\
\hline Illiq collat & 4,840 & 1.2 & 2 & 0 & 5.3 \\
\hline Liq collat & 4,840 & 6.9 & 10.2 & 0 & 19.3 \\
\hline Tot collat & 4,840 & 8 & 10.3 & 0 & 20.8 \\
\hline Bonds held & 4,791 & 18.2 & 10.5 & .7 & 37.6 \\
\hline Loans & 4,840 & 54.6 & 18.1 & 25.1 & 79 \\
\hline Debt issued & 4,840 & 15.5 & 17 & 0 & 49.7 \\
\hline Interbank lending & 4,840 & 13.3 & 11.5 & 1.6 & 32.9 \\
\hline Interbank borrowing & 4,840 & 21 & 17.3 & 2.9 & 57.5 \\
\hline Net interbank position & 4,840 & -7.7 & 16.3 & -35.3 & 13.1 \\
\hline $\mathrm{CB}$ refinancing & 4,840 & 3.5 & 5.5 & 0 & 15.4 \\
\hline Capital ratio & 4,840 & 8.8 & 6.3 & 2.1 & 19.1 \\
\hline Rating & 2,435 & 6.8 & 3.2 & 3 & 13 \\
\hline
\end{tabular}

Note: All variables as a \% of total assets except Rating for which 1=AAA and an increment of 1 corresponds to one notch.

Reading: Among banks that experienced at least one period of run during our period under review, the mean of bonds held normalized by the total asset was $18.2 \%$ between $2011 \mathrm{~m} 1$ and $2014 \mathrm{~m} 12$.

Source: IBSI database, Banque de France and authors' computations.

( $15 \%$ vs. $16 \%)$ either. On average the banks that were run tend to pledge more collateral with the Eurosystem, which is consistent with a greater reliance on the Eurosystem refinancing (3.5\% against $1.8 \%$ of $\mathrm{CB}$ refinancing). Finally, the two groups of banks do not differ in terms of the average share of credit claims that they pledge with the Eurosystem, with an average equal to $1 \%$ of total assets in both cases. Credit ratings, available for a subset of banks in our datasets, do not display major differences, with the average rating of banks run being lower by less than one notch than the ratings of banks never run.

Tables A2 and A3 in the appendix report the same statistics but as of $2011 \mathrm{~m} 1$, that is at the beginning of the period of study, to allow a comparison at the same date. This statistic only gives an incomplete picture of the statistics of the average bank run as only half of the banks run had started already by January 2011 . Yet the averages are strikingly similar to those in table 4 and 5. The comparison of tables A1 and A2 shows that the average reliance of banks on the interbank market is similar across bank categories: in January 2011, the banks that are run are not more reliant on the interbank market. The statistics also confirm that banks are similar in terms of level of loans granted or bonds held, suggesting that there was no striking difference between the average bank that was run and the average bank that was not run in January 2011.
We now turn to compare whether the banks that pledge more than $1 \%$ of their balance sheet in illiquid collateral differ from those that pledge less than $1 \%$ (Tables 5 and 6 ). Banks that pledge more than $1 \%$ of their assets in illiquid collateral tend to have marginally fewer loans in their balance sheet, and rely more on debt issuance to fund their assets. They are more active in intermediating the interbank market, both borrowing and lending more to other banks. They borrow $31 \%$ and lend $20 \%$ of their balance sheet to other MFIs. By contrast, those pledging less than $1 \%$ have the same net interbank position, at $-11 \%$, but borrow only $26 \%$ and lend $14 \%$ of their balance sheet. Interestingly, the central bank refinancing secured by the former is lower than the borrowing of the latter. This suggests that banks that are the most reliant on Eurosystem refinancing do not use more illiquid collateral.

\section{Specification and results}

We present the specification of the regressions used for the impact of the composition of banks' collateral pools on their lending activity, then we discuss the results.

\section{Specification and identification strategy}

We hypothesize that the composition of the collateral pools pledged with the central bank 
Table 5

Summary statistics, banks pledging less than $1 \%$ of their balance sheet in credit claims, as of $2011 \mathrm{~m} 1$

\begin{tabular}{|l|c|c|c|c|c|}
\hline \multicolumn{1}{|c|}{ Variable } & Obs. & Mean & Std. Dev. & P5 & P95 \\
\hline Run & 133 & 3.8 & 8.2 & 0 & 18.4 \\
Illiq collat & 133 & .1 & .2 & 0 & .7 \\
Liq collat & 133 & 5.2 & 8.1 & 0 & 14.9 \\
Tot collat & 133 & 5.3 & 8.1 & 0 & 14.9 \\
Bonds held & 129 & 16.6 & 9.8 & 1.3 & 31.4 \\
Loans & 133 & 56.1 & 19.8 & 16.9 & 83.9 \\
Debt issued & 133 & 14.2 & 15.3 & 0 & 45.9 \\
Interbank lending & 133 & 14.3 & 12.8 & 2 & 40.5 \\
Interbank borrowing & 133 & 25.5 & 19.9 & 4.3 & 65.9 \\
Net interbank position & 133 & -11.3 & 19.5 & -51.7 & 11.8 \\
CB refinancing & 133 & 2 & 5 & 0 & 11.7 \\
Capital ratio & 133 & 7.7 & 4.2 & 1.7 & 14.8 \\
\hline Rating & 60 & 5.4 & 2 & 2.5 & 9 \\
\hline
\end{tabular}

Note: All variables as a \% of total assets except Rating for which 1=AAA and an increment of 1 corresponds to one notch.

Reading: Among banks that used to pledge less than $1 \%$ of their total asset in credit claims with the Eurosystem as of $2011 \mathrm{~m} 1$, the mean of bonds held normalized by the total asset was $16.6 \%$ as of $2011 \mathrm{~m} 1$.

Source: IBSI database, Banque de France and authors' computations.

Table 6

Summary statistics, banks pledging more than $1 \%$ of their balance sheet in credit claims, as of $2011 \mathrm{~m} 1$

\begin{tabular}{|l|c|c|c|c|c|}
\hline \multicolumn{1}{|c|}{ Variable } & Obs. & Mean & Std. Dev. & P5 & P95 \\
\hline Run & 44 & 2.4 & 4.8 & 0 & 14.3 \\
Illiq collat & 44 & 2.7 & 1.8 & 1.1 & 6.1 \\
Liq collat & 44 & 4 & 4.6 & 0 & 10.6 \\
Tot collat & 44 & 6.7 & 4.7 & 1.5 & 12.6 \\
Bonds held & 44 & 15.9 & 9.4 & 1.4 & 30.8 \\
Loans & 44 & 47 & 19.4 & 17.5 & 79.1 \\
Debt issued & 44 & 23.4 & 21.6 & .5 & 86.2 \\
Interbank lending & 44 & 19.9 & 15.4 & 5.3 & 47 \\
Interbank borrowing & 44 & 31.4 & 18.7 & 5.3 & 64.3 \\
Net interbank position & 44 & -11.5 & 18.9 & -44.3 & 3.7 \\
CB refinancing & 44 & .9 & 1.7 & 0 & 4.6 \\
Capital ratio & 44 & 6.8 & 3.2 & 3.2 & 13.6 \\
\hline Rating & 28 & 4.5 & 1.7 & 1 & 7 \\
\hline
\end{tabular}

Note: All variables as a \% of total assets except Rating for which 1=AAA and an increment of 1 corresponds to one notch.

Reading: Among banks that used to pledge more than $1 \%$ of their total asset in credit claims with the Eurosystem as of $2011 \mathrm{~m} 1$, the mean of bonds held normalized by the total asset was $15.9 \%$ as of $2011 \mathrm{~m} 1$.

Source: IBSI database, Banque de France and authors' computations.

matters for the supply of loans to the economy. More precisely, we are interested in determining whether the share of marketable versus non-marketable assets is neutral on banks' behavior. This may matter for two reasons. First, the cash-equivalent of marketable assets is pro-cyclical, i.e. the cash that can be obtained by selling or collateralizing those assets varies with the market price. The implication is that when the price decreases, the value of the asset as collateral also decreases. This is the financial accelerator mechanism highlighted by Kiyotaki and Moore (1997). By contrast, non-marketable assets are less pro-cyclical since their valuation only depends on their default probability (supra). Therefore, the ability to pledge non-marketable assets insures against price variations. Second, marketable assets have alternative uses such as the ability of being repo-ed on the securitized interbank market or sold quickly 
on demand. By contrast, credit claims are mainly useful as collateral for central bank refinancing operations, as selling credit claims is costly and lengthy since this requires securitizing them in the form of asset-backed securities or covered bonds. In other words, the opportunity cost of pledging such assets is lower than for other marketable securities. Therefore, when accepting credit claims as collateral, the central bank is relaxing the borrowing constraint of banks (Ahn et al., 2016).

In the absence of an active European securitization market, a run on a sufficient number of banks leads to an aggregate loss of wholesale funding which may trigger a credit crunch. In such a situation, the collateral framework -with respect to quantity and composition- is likely to matter as banks are increasing their demand for central bank reserves. In such a situation, the collateral framework may impact on banks' decision to lend in two cases. In the first case, a bank that is run may decide to pledge more credit claims with the central bank in order to maintain its lending to the economy. In the second case, when competitors are run and the wholesale funding market is frozen, well-capitalized banks that are not run may increase their refinancing with the central bank in order to secure the resources necessary to increase their lending activity to the economy and eventually increase their market share. In a nutshell, by making credit claims eligible collateral, the Eurosystem modifies the incentives to lend to the economy in a period during which holding illiquid assets is less desirable than holding liquid assets.

To test this hypothesis on our subsample of 177 euro area banks from Jan-2011 to Dec-2014, we regress the loans to non-financial agents (households and non- financial corporations) on the intensity of the variable measuring the run and the variables measuring the composition of the collateral pledged with the central bank. We are primarily interested in determining whether the coefficient of the illiquid variable is significantly greater than zero, i.e. whether a bank's ability to pledge more illiquid collateral increases its lending to the economy. The regression equation reads as follows:

$$
\begin{aligned}
& \text { Loans }_{b k, t}= \\
& \text { LLoans }_{b k, t-1}-\alpha \text { Capital ratio }_{b k, t-1}+ \\
& \beta \text { Illiq }+ \text { Liq collat }_{b k, t}+\epsilon \text { Illiq collat }_{b k, t}+ \\
& \gamma \text { Run }_{b k, t-1}+\delta\left[\text { Run }_{b k, t-1}^{*} \quad \text { Illiq }_{+} \text {Liq collat }_{b k, t}\right]+ \\
& \xi\left[\text { Run }_{b k, t-1}^{*} \quad \text { Illiq collat }_{b k, t}\right]+F E_{b k}+F E_{c o u n t r y, t}+\varepsilon_{b k, t}
\end{aligned}
$$

where the index $b k(\mathrm{t})$ denotes a bank (the date, month and year).To account for the inertia in loan creation, we also include the lagged dependent variable as an explanatory variable. All of the variables are computed as a share of the lagged total assets of the bank to take account of the fact that banks vary in size and to make them comparable.

We focus on the variables Totcollat $_{b k, t}$ and Illiq collat $_{b k, t}$ which stand for the total volume of collateral and the volume of illiquid assets pledged with the central bank respectively. The coefficient $\beta$ measures to what extent the volume of collateral pledged by a bank increases its loan supply. The coefficient $\epsilon$ assesses whether credit claims play an additional role in determining lending decisions. We expect both to be positive. The variable $\operatorname{Run}_{b k, t-1}$ stands for the intensity of the run at the bank level for the previous month (see Section 4 for details). We expect its coefficient $\gamma$ to be negative.

We also include interactions between this $R_{u n}{ }_{b k, t-1}$ variable and each collateral variable to allow for a non-linear impact of collateral in times of wholesale funding loss. Note that the pledging of illiquid collateral takes time and comes with significant legal costs like the physical delivery of credit documentation to the central bank in some jurisdictions (Tamura \& Tabakis, 2013) $)^{17}$. It is therefore very unlikely that newly originated loans are pledged as collateral with the Eurosystem over the couple of months that follow their origination. We believe that a contemporaneous positive and significant relationship between loans and illiquid collateral can hardly result from the pledging of newly originated loans.

We finally include some control variables to account for potential confounding factors in the regression. The variable $F E_{b k}$ denotes the inclusion of bank fixed-effects to account for the heterogeneity of banks' business models. The variable $F E_{\text {country,t }}$ corresponds to the country-time fixed effects. They capture potential country-specific shocks on the banking sector

17. See Tamura and Tabakis (2013): "The relatively high operational costs of the use of credit claims as collateral can also be seen in the additional eligibility and operational requirements for credit claims that are not required for marketable assets (see Table A1). The requirements relate to: (i) ex ante notification of the debtor about mobilisation (in some jurisdictions); (ii) physical delivery of related loan documents; (iii) transferability of credit claims; and (iv) reporting requirement of counterparties regarding the existence of credit claims. These conditions which are directly required by national legislations (e.g. i and iii) or reflect central bank policies (e.g. iv) imply that credit claims are not normally assets which are expected to trade with high frequency." 
as well as common shocks affecting demand for loans. The underlying assumption is that banks face relatively homogenous demand for loans in a specific country. We also control for the quality of banks by including the capital ratio (computed as the ratio of equity to lagged total assets). Residuals are clustered at the bank level to allow for heterogeneity in the distribution of shocks at the bank level. The residual of the regression is denoted by $\varepsilon_{b k, t}$.

\section{Results}

Table 7 reports the main regression estimates in which we introduce one explanatory variable after another. The results show that an increase in the volume of illiquid collateral pledged with the central bank is associated with a significant increase in loans to the economy. The coefficient of Illiq collat $_{b k, t}$ shows that a 1 percentage point increase in the volume of illiquid collateral pledged with the central bank (as a percentage of the bank's total assets) leads to about a 0.3 percentage point increase in the loans-to-total-assets ratio. This is economically significant as a one standard deviation increase in the volume of illiquid collateral leads to a 0.6 percentage point increase in the loans-to-total-assets ratio or to a $1.1 \%$ increase of lending activity, which is consistent with our hypothesis that the eligibility of illiquid collateral boosts bank lending activity. If the increase in the volume of illiquid collateral is temporary, the corresponding 0.6 percentage point increase of lending activity is also short-living and disappears exponentially at the rate of $23 \%$ each month according to our estimates.

We also find a positive correlation between the total volume of collateral pledged (irrespective of its liquidity) and loans. Our main contribution is to stress, for a given level of collateral pledged, the importance of the liquidity composition of the collateral pool for lending activity. Eligible credit claims, with low default probability, are unlikely to raise moral hazard issues. In addition, to account for the quality of banks, we include the capital ratio in the estimates. The capital ratio is positive and significant suggesting that an increase in the capital ratio is associated with more loans to the economy.

The wholesale funding loss as measured by Run $_{b k, t-1}$ has a significant and negative impact on bank lending. The impact is significant. For a 1 standard deviation of the run intensity for banks that are hit by a run at least once in our sample -i.e. a 9\% loss of wholesale fundingthe bank reduces its loans-to-total-assets ratio by 0.5 percentage point or the total lending by around $0.9 \%$. The impact of the loss of wholesale funding on loans is attenuated when banks pledge more collateral with the central bank: the interaction between the intensity of the run and the total volume of collateral is positive and

Table 7

Bank loans and collateral liquidity

\begin{tabular}{|c|c|c|c|c|c|c|}
\hline & $\begin{array}{l}(1) \\
\text { Loans }\end{array}$ & $\begin{array}{c}(2) \\
\text { Loans }\end{array}$ & $\begin{array}{c}(3) \\
\text { Loans }\end{array}$ & $\begin{array}{c}(4) \\
\text { Loans }\end{array}$ & $\begin{array}{c}(5) \\
\text { Loans }\end{array}$ & $\begin{array}{c}(6) \\
\text { Loans }\end{array}$ \\
\hline Loans (t-1) & $\begin{array}{l}0.774^{* \star *} \\
(0.0443)\end{array}$ & $\begin{array}{l}0.771^{\star * *} \\
(0.0451)\end{array}$ & $\begin{array}{l}0.771^{\text {**}} \\
(0.0446)\end{array}$ & $\begin{array}{l}0.772^{* * *} \\
(0.0446)\end{array}$ & $\begin{array}{l}0.769^{* \star *} \\
(0.0454)\end{array}$ & $\begin{array}{l}0.765^{\star \star \star} \\
(0.0457)\end{array}$ \\
\hline Capital ratio & $\begin{array}{c}0.425^{\star \star *} \\
(0.119)\end{array}$ & $\begin{array}{c}0.430^{\star \star *} \\
(0.119)\end{array}$ & $\begin{array}{c}0.439^{* * *} \\
(0.128)\end{array}$ & $\begin{array}{l}0.443^{* * *} \\
(0.128)\end{array}$ & $\begin{array}{c}0.447^{\star * \star} \\
(0.128)\end{array}$ & $\begin{array}{c}0.446^{\star \star \star \star} \\
(0.128)\end{array}$ \\
\hline Tot collat & $\begin{array}{l}0.0250^{* * *} \\
(0.00737)\end{array}$ & $\begin{array}{l}0.0230^{* * *} \\
(0.00807)\end{array}$ & & $\begin{array}{l}0.0266^{* *} \\
(0.00693)\end{array}$ & $\begin{array}{l}0.0245^{* *} \\
(0.00729)\end{array}$ & $\begin{array}{l}0.0265^{\star *} \\
(0.0119)\end{array}$ \\
\hline Illiq collat & & $\begin{array}{l}0.282^{* \star *} \\
(0.0881)\end{array}$ & & & $\begin{array}{l}0.277^{\star * *} \\
(0.0862)\end{array}$ & $\begin{array}{l}0.279^{\star \star *} \\
(0.0868)\end{array}$ \\
\hline Run & & & $\begin{array}{l}-0.0235 \\
(0.0245)\end{array}$ & $\begin{array}{l}-0.0261 \\
(0.0244)\end{array}$ & $\begin{array}{c}-0.0252 \\
(0.0242)\end{array}$ & $\begin{array}{l}0.0564^{* *} \\
(0.0249)\end{array}$ \\
\hline Run $\times$ Tot collat & & & & & & $\begin{array}{l}0.248^{* *} \\
(0.101)\end{array}$ \\
\hline Run $\times$ Illiq collat & & & & & & $\begin{array}{r}-0.265 \\
(0.609)\end{array}$ \\
\hline Adjusted $R^{2}$ & 0.662 & 0.664 & 0.662 & 0.663 & 0.664 & 0.666 \\
\hline Observations & 8,221 & 8,221 & 8,221 & 8,221 & 8,221 & 8,221 \\
\hline
\end{tabular}

Standard errors in parentheses. All variables at the bank level.

Note: Panel regression with residuals clustered at bank level, time, bank and country-time fixed effects. ${ }^{*} p<0.10,{ }^{* *} p<0.05,{ }^{* * *} p<0.01$. 
significant in most specifications (including in Table A5 when we control for banks' ratings).

\section{Robustness check}

We also conduct robustness exercises. The first robustness exercise consists in replacing the variable Illiq collat $_{b k, t}$ in equation (2) by the difference between the volume of illiquid assets pledged and the volume of liquid assets pledged Illiq-_iq collat ${ }_{b k, t}$. The coefficient in front of this variable can be interpreted as the impact of increasing the share of illiquid assets in the collateral pool while keeping the total volume collateral unchanged.

The second robustness check removes the last semester from the estimation period. Indeed, some may be concerned by the fact that the Targeted Longer-Term Refinancing Operations
(TLTROs) launched in June 2014 may have altered the relationship between bank lending and the refinancing activity of the bank.

The third robustness check consists in including the bank's rating as an additional control variable for the quality of banks. Given that ratings are available only for a subset of banks, it substantially reduces the sample size.

Table 8 gives the result of changing the specification of the variable measuring the impact of illiquid collateral on bank lending. The result shows that there is a clear composition effect, as the coefficient of the variable Illiq - Liq collat ${ }_{b k, t}$ is positive and significant. Finally, the results are unchanged when we exclude the last semester from the estimation period in Table A4 or when we control for bank ratings in Table A5.

Table 8

Bank loans and collateral liquidity

\begin{tabular}{|c|c|c|c|c|c|c|}
\hline & $\begin{array}{l}(1) \\
\text { Loans }\end{array}$ & $\begin{array}{c}(2) \\
\text { Loans }\end{array}$ & $\begin{array}{c}\text { (3) } \\
\text { Loans }\end{array}$ & $\begin{array}{l}(4) \\
\text { Loans }\end{array}$ & $\begin{array}{c}(5) \\
\text { Loans }\end{array}$ & $\begin{array}{c}(6) \\
\text { Loans }\end{array}$ \\
\hline Loans (t-1) & $\begin{array}{l}0.774^{* * *} \\
(0.0443)\end{array}$ & $\begin{array}{l}0.771^{* \star *} \\
(0.0451)\end{array}$ & $\begin{array}{l}0.771^{* * *} \\
(0.0446)\end{array}$ & $\begin{array}{l}0.772^{\star \star *} \\
(0.0446)\end{array}$ & $\begin{array}{l}0.769^{* \star *} \\
(0.0454)\end{array}$ & $\begin{array}{l}0.765^{\text {** }}(0.0457)\end{array}$ \\
\hline Capital ratio & $\begin{array}{l}0.424^{* * *} \\
(0.119)\end{array}$ & $\begin{array}{c}0.430^{\star \star *} \\
(0.119)\end{array}$ & $\begin{array}{c}0.439^{* * *} \\
(0.128)\end{array}$ & $\begin{array}{l}0.442^{\star \star *} \\
(0.128)\end{array}$ & $\begin{array}{c}0.447^{\star * *} \\
(0.128)\end{array}$ & $\begin{array}{c}0.446^{* * \star} \\
(0.128)\end{array}$ \\
\hline Tot collat & $\begin{array}{l}0.0250^{* * *} \\
(0.00745)\end{array}$ & $\begin{array}{l}0.164^{\star \star *} \\
(0.0439)\end{array}$ & & $\begin{array}{l}0.0265^{\star * *} \\
(0.00697)\end{array}$ & $\begin{array}{l}0.163^{* * *} \\
(0.0431)\end{array}$ & $\begin{array}{c}0.166^{* *} \\
(0.0443)\end{array}$ \\
\hline Illiq - Liq collat & & $\begin{array}{l}0.141^{* * *} \\
(0.0440)\end{array}$ & & & $\begin{array}{l}0.139^{\star * *} \\
(0.0431)\end{array}$ & $\begin{array}{l}0.140^{* * *} \\
(0.0434)\end{array}$ \\
\hline Run & & & $\begin{array}{l}-0.0235 \\
(0.0246)\end{array}$ & $\begin{array}{l}-0.0262 \\
(0.0243)\end{array}$ & $\begin{array}{l}-0.0252 \\
(0.0242)\end{array}$ & $\begin{array}{l}0.0564^{\star \star} \\
(0.0249)\end{array}$ \\
\hline Run $\times$ Tot collat & & & & & & $\begin{array}{c}0.115 \\
(0.299)\end{array}$ \\
\hline Run $\times$ Illiq - Liq collat & & & & & & $\begin{array}{l}-0.133 \\
(0.304)\end{array}$ \\
\hline Adjusted $R^{2}$ & 0.662 & 0.664 & 0.662 & 0.663 & 0.664 & 0.666 \\
\hline Observations & 8,221 & 8,221 & 8,221 & 8,221 & 8,221 & 8,221 \\
\hline
\end{tabular}

Standard errors in parentheses. All variables at the bank level.

Note: Panel regression with residuals clustered at bank level, time, bank and country-time fixed effects.

${ }^{*} p<0.10,{ }^{* *} p<0.05,{ }^{* \star *} p<0.01$.

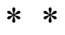

We study the impact of banks' ability to pledge illiquid collateral on their lending activity during the European sovereign debt crisis. By doing so, they were able to convert illiquid loans into liquid reserves at the central bank. To identify the beneficial impact of the (il)liquidity of collateral on the loan supply of individual banks, we make use of the differences in the share of illiquid collateral banks are able to pledge. This proportion varies both in the cross-section and in the time series. We then show that banks that pledged more illiquid assets against central bank reserves were those that reduced their lending to the economy less. 
Abbassi, P., Bräuning, F, Fecht, F. \& Peydro, J.-L. (2014). Cross-border liquidity, relationships and monetary policy: Evidence from the euro area interbank crisis. Deutsche Bundesbank, Discussion Papers 45 / 2014.

Acharya, V. \& Steffen, S. (2015). The greatest carry trade ever? Understanding eurozone bank risks. Journal of Financial Economics, 115, 215-236.

Ahn, J.-H., Bignon, V., Breton, R. \& Martin, A. (2016). Interbank market and central bank policy. Federal Reserve Bank of New York, Staff Report 763.

Bagehot, W. (1873). Lombard Street: a description of the money market (5th ed.). London: Henry S. King and Co.

Bernanke, B. (1983). Non-monetary Effects of the Financial Crisis in the Propagation of the Great Depression. American Economic Review 73(3), 257-276.

Bignon, V., Boissay, F., Cahn, C. \& Harpedanne de Belleville, L.-M. (2016). Extended eligibility of credit claims for Eurosystem refinancing Consequences for the supply of credit to companies. Quarterly selection of articles - Bulletin de la Banque de France, 43, 15-23.

Bignon, V. \& Jobst, C. (2017). Economic crises and the eligibility for the lender of last resort: evidence from France. Banque de France, Working paper $\mathrm{N}^{\circ} 618$.

Bindseil, U. (2013). Central bank collateral, asset fire sales, regulation and liquidity. European Central Bank Working Paper $\mathrm{N}^{\circ} 1610$.

Bindseil, U. (2014). Monetary Policy Implementation: Theory, Past and Present. Oxford: Oxford University Press.

Bindseil, U. \& Jablecki, J. (2013). Central bank liquidity provision, risk-taking and economic efficiency. European Central Bank Working Paper $\mathrm{N}^{\circ} 1542$.

Bindseil, U. \& Papadia, F. (2007). Risk management and market impact of central bank credit operations. Bindseil et al. (Eds). Risk management for central bank and other public investors. Oxford: Oxford University Press, 271-302.

BIS (2013). Central bank collateral frameworks and practices. Technical report.
Bryant, J. (1980). A model of reserves, bank runs, and deposit insurance. Journal of Banking and Finance, 4, 335-344.

Chernenko, S. \& Sunderam, A. (2014). Frictions in shadow banking: Evidence from the lending behavior of money market mutual funds. Review of Financial Studies, 27(6),1717-1750.

Claeys, G. (2014). The (not so) Unconventional Monetary Policy of the European Central Bank since 2008. European Parliament's Committee on Economy and Monetary Affairs, June.

Cornett, M. M., McNutt, J. J., Strahan, P. E. \& Tehranian, H. (2011). Liquidity risk management and credit supply in the financial crisis. Journal of Financial Economics, 101(2), 297-312.

Correa, R., Sapriza, H. \& Zlate, A. (2013). Liquidity shocks, dollar funding costs, and the bank lending channel during the European sovereign crisis. Board of Governors of the Federal Reserve System, International Finance Discussion Papers.

de Haan, L., End, J. W. \& Vermeulen, P. (2015). Lenders on the storm of wholesale funding shocks: Saved by the central bank? De Neerlandsche Bank, Working Paper $\mathrm{N}^{\circ} 456$.

Diamond, D. W. (1996). Financial intermediation as delegated monitoring: A simple example. FRB Richmond Economic Quarterly, 82(3),51-66.

Diamond, D. W. \& Dybvig, P. (1983). Bank runs, deposit insurance, and liquidity. Journal of Political Economy, 91(3), 401-419.

Diamond, D. W. \& Rajan, R. G. (2005). Liquidity shortages and banking crises. Journal of Finance, 60(2), 615-647.

ECB (2012). Implementation of new collateral rules and reserve requirements. ECB Monthly Bulletin, 2, 29-30, Box 2.

ECB (2013). Collateral eligibility requirements: A comparative study across specific frameworks. Report on collateral frameworks.

Friedman, M. \& Schwartz, A (1961). A Monetary History of the United States, 1867-1960. Princeton: Princeton University Press. 
Frutos, J. C., Garcia-de Andoain, C., Heider, F. \& Papsdorf, P. (2016). Stressed interbank markets: evidence from the European financial and sovereign debt crisis. European Central Bank, Working Paper Series $N^{\circ} 1925$.

Gorton, G. \& Metrick, A. (2012). Who ran on repo? NBER Working Papers $\mathrm{N}^{\circ} 18455$.

Gorton, G. \& Winton, A. (2003). Financial Intermediation. The Handbook of the Economics of Finance. Amsterdam: Elsevier Science.

Ivashina, V., Scharfstein, D. S. \& Stein, J. C. (2015). Dollar funding and the lending behavior of global banks. The Quarterly Journal of Economics 130(3),1241-1281. doi:10.1093/qje/qjv017.

Kashyap, A. K., Rajan, R. \& Stein, J. C. (2000). Banks as liquidity providers: An explanation for the co-existence of lending and deposit-taking. Journal of Finance, 57(1), 33-73.

Kashyap, A. K. \& Stein, J. C. (2000). What do a million banks have to say about the transmission of monetary policy? American Economic Review, 90(3), 407-428.

Kiyotaki, N. \& Moore, J. (1997). Credit cycles. Journal of Political Economy, 105(2), 211-248.

Loutskina, E. \& Strahan, P. E. (2009). Securitization and the declining impact of bank finance on loan supply: Evidence from mortgage acceptance rates. Journal of Finance, 64(2), 861-889.
Mancini, L., Ranaldo, A. \& Wrampelmeyer, J. (2016). The euro interbank repo market. Review of Financial Studies 29(7), 1747-1779. doi: 10.1093/rfs/hhv056.

Marx, M., Nguyen, B., \& Sahuc, J.-G. (2016). Monetary policy measures in the euro area and their effects since 2014. Banque de France, Rue de la Banque $\mathrm{N}^{\circ} 32$.

Nyborg, K. G. \& Strebulaev, I. A. (2001). Collateral and short squeezing of liquidity in fixed rate tenders. Journal of International Money and Finance, 20(6), 769-792.

Perignon, C., Thesmar, D. \& Vuillemey, G. (2017). Wholesale funding dry-ups. Journal of Finance, Forthcoming.

Sauerzopf, B. (2007). Credit claims as eligible collateral for Eurosystem credit operations. OeNB Monetary Policy and the Economy, Q2, 80-92.

Singh, M. \& Stella, P. (2012). Money and collateral. International Monetary Fund, Working Papers $\mathrm{N}^{\circ} 12 / 95$.

Tamura, K. \& Tabakis, E. (2013). The use of credit claims as collateral for Eurosystem credit operations. European Central Bank, Occasional Paper Series $\mathrm{N}^{\circ} 148$.

Thornton, H. (1802). An enquiry into the nature and effects of the paper credit of Great Britain. London: Knight and Compton. 
Table A1

Haircut grid applicable to credit claims used as collateral, as a \%

\begin{tabular}{|l|cc|cc|c|}
\hline Residual mat. & \multicolumn{2}{|c|}{ Valuation (1) } & \multicolumn{2}{c|}{ Valuation (2) } & RMB debt (3) \\
\hline & AAA to A & BBB+ to BBB- & AAA to A & BBB+ to BBB- & AAA to A- \\
\hline$<1 y$ & 10 & 17 & 12 & 19 & 39.5 \\
$1-3 y$ & 12 & 29 & 16 & 34 & 39.5 \\
$3-5 y$ & 14 & 37 & 21 & 46 & 39.5 \\
$5-7 y$ & 17 & 39 & 27 & 52 & 39.5 \\
$7-10 y$ & 22 & 40 & 35 & 58 & 39.5 \\
$10 y$ & 30 & 42 & 45 & 65 & 39.5 \\
\hline
\end{tabular}

Note: Valuation (1) and Valuation (2) are based on a theoretical price assigned by the NCB and on the outstanding amount assigned by the NCB respectively; last column (3) is for non-marketable residential mortgage-backed debt.

Source: ECB (https://www.ecb.europa.eu/mopo/assets/risk/liquidity/html/index.en.html).

Table A2

Summary statistics, banks never run, as of $2011 \mathrm{~m} 1$

\begin{tabular}{|c|c|c|c|c|c|}
\hline Variable & Obs. & Mean & Std. Dev. & P5 & P95 \\
\hline Run & 75 & 0 & 0 & 0 & 0 \\
\hline Illiq. collat & 75 & .7 & 1.4 & 0 & 2.8 \\
\hline Liq. collat & 75 & 3.4 & 3.3 & 0 & 10.7 \\
\hline Tot. collat & 75 & 4.1 & 3.6 & 0 & 10.8 \\
\hline Bonds held & 72 & 15.3 & 8.9 & 1.4 & 29.3 \\
\hline Loans & 75 & 53.3 & 21.2 & 11.9 & 87.4 \\
\hline Debt issued & 75 & 16.9 & 17.9 & 0 & 46.5 \\
\hline Interbank lending & 75 & 17.3 & 15.7 & 2.2 & 47.4 \\
\hline Interbank borrowing & 75 & 28.5 & 21.8 & 4.3 & 76.6 \\
\hline Net interbank position & 75 & -11.1 & 21.5 & -53.1 & 19.8 \\
\hline $\mathrm{CB}$ refinancing & 75 & 1 & 2.3 & 0 & 6.9 \\
\hline Capital ratio & 75 & 7.4 & 3.6 & 2.4 & 14 \\
\hline Rating & 40 & 4.8 & 1.7 & 1 & 7.5 \\
\hline
\end{tabular}

Note: All variables as a \% of total assets except Rating for which 1=AAA and an increment of 1 corresponds to one notch.

Reading: Among banks that never experienced a run during our period under review, the mean of bonds held normalized by the total asset was

$15.5 \%$ as of $2011 \mathrm{~m} 1$.

Source: IBSI database, Banque de France and authors' computations. 
Table A3

Summary statistics, banks run at least once $(2011 \mathrm{~m} 1-2014 \mathrm{~m} 12)$, as of $2011 \mathrm{~m} 1$

\begin{tabular}{|c|c|c|c|c|c|}
\hline Variable & Obs. & Mean & Std. Dev. & P5 & P95 \\
\hline Run & 102 & 6 & 9.1 & 0 & 18.6 \\
\hline Illiq collat & 102 & .8 & 1.5 & 0 & 4.1 \\
\hline Liq collat & 102 & 6 & 9.1 & 0 & 18.3 \\
\hline Tot collat & 102 & 6.8 & 9.1 & 0 & 18.3 \\
\hline Bonds held & 101 & 17.3 & 10.1 & .3 & 33.2 \\
\hline Loans & 102 & 54.2 & 19.2 & 21.9 & 79.1 \\
\hline Debt issued & 102 & 16.1 & 17.3 & .1 & 54.8 \\
\hline Interbank lending & 102 & 14.5 & 12 & 1.7 & 34 \\
\hline Interbank borrowing & 102 & 25.9 & 18.1 & 4.7 & 59.1 \\
\hline Net interbank position & 102 & -11.4 & 17.5 & -44.3 & 7.3 \\
\hline $\mathrm{CB}$ refinancing & 102 & 2.4 & 5.4 & 0 & 12.2 \\
\hline Capital ratio & 102 & 7.6 & 4.3 & 1.7 & 14.1 \\
\hline Rating & 48 & 5.4 & 2.1 & 2 & 9 \\
\hline
\end{tabular}

Note: All variables as a \% of total assets except Rating for which 1=AAA and an increment of 1 corresponds to one notch.

Reading: Among banks that experienced at least one period of run during our period under review, the mean of bonds held normalized by the total asset was $17.3 \%$ as of $2011 \mathrm{~m} 1$.

Source: IBSI database, Banque de France and authors' computations.

Table A4

Bank loans and collateral liquidity, subsample 2011m1-2014m6

\begin{tabular}{|c|c|c|c|c|c|c|}
\hline & $\begin{array}{c}(1) \\
\text { Loans }\end{array}$ & $\begin{array}{c}(2) \\
\text { Loans }\end{array}$ & $\begin{array}{l}\text { (3) } \\
\text { Loans }\end{array}$ & $\begin{array}{l}\text { (4) } \\
\text { Loans }\end{array}$ & $\begin{array}{l}(5) \\
\text { Loans }\end{array}$ & $\begin{array}{c}(6) \\
\text { Loans }\end{array}$ \\
\hline Loans (t-1) & $\begin{array}{l}0.754^{* * *} \\
(0.0499)\end{array}$ & $\begin{array}{l}0.751^{* * *} \\
(0.0506)\end{array}$ & $\begin{array}{l}0.750^{\star \star *} \\
(0.0505)\end{array}$ & $\begin{array}{l}0.751^{* * *} \\
(0.0505)\end{array}$ & $\begin{array}{l}0.749^{* * *} \\
(0.0511)\end{array}$ & $\begin{array}{l}0.746^{* \star *} \\
(0.0515)\end{array}$ \\
\hline Capital ratio & $\begin{array}{c}0.464^{\star * *} \\
(0.135)\end{array}$ & $\begin{array}{c}0.469^{\star * *} \\
(0.135)\end{array}$ & $\begin{array}{l}0.490^{* * *} \\
(0.149)\end{array}$ & $\begin{array}{c}0.491^{* * *} \\
(0.149)\end{array}$ & $\begin{array}{c}0.494^{* * *} \\
(0.148)\end{array}$ & $\begin{array}{c}0.498^{* * *} \\
(0.151)\end{array}$ \\
\hline Tot collat & $\begin{array}{l}0.0291^{* * *} \\
(0.00856)\end{array}$ & $\begin{array}{l}0.0271^{* * *} \\
(0.00948)\end{array}$ & & $\begin{array}{l}0.0315^{* * *} \\
(0.00744)\end{array}$ & $\begin{array}{l}0.0295^{\star * *} \\
(0.00810)\end{array}$ & $\begin{array}{l}0.0297^{* *} \\
(0.0126)\end{array}$ \\
\hline Illiq collat & & $\begin{array}{c}0.291^{* * *} \\
(0.102)\end{array}$ & & & $\begin{array}{l}0.280^{* * *} \\
(0.0980)\end{array}$ & $\begin{array}{l}0.285^{\star * *} \\
(0.0988)\end{array}$ \\
\hline Run & & & $\begin{array}{l}-0.0295 \\
(0.0276)\end{array}$ & $\begin{array}{l}-0.0334 \\
(0.0269)\end{array}$ & $\begin{array}{l}-0.0319 \\
(0.0268)\end{array}$ & $\begin{array}{c}-0.0626^{* *} \\
(0.0291)\end{array}$ \\
\hline Run $\times$ Tot collat & & & & & & $\begin{array}{l}0.239^{\star \star *} \\
(0.0941)\end{array}$ \\
\hline Run $\times$ Illiq collat & & & & & & $\begin{array}{l}-0.197 \\
(0.666)\end{array}$ \\
\hline Adjusted $R^{2}$ & 0.628 & 0.629 & 0.628 & 0.629 & 0.630 & 0.632 \\
\hline Observations & 7,206 & 7,206 & 7,206 & 7,206 & 7,206 & 7,206 \\
\hline
\end{tabular}

Standard errors in parentheses. All variables at the bank level.

Note: Panel regression with residuals clustered at bank level, time, bank and country-time fixed effects.

${ }^{*} p<0.10,{ }^{* *} p<0.05,{ }^{* * *} p<0.01$. 
Table A5

Bank loans and collateral liquidity when controlling for credit rating

\begin{tabular}{|c|c|c|c|c|c|c|}
\hline & $\begin{array}{l}(1) \\
\text { Loans }\end{array}$ & $\begin{array}{l}(2) \\
\text { Loans }\end{array}$ & $\begin{array}{c}\text { (3) } \\
\text { Loans }\end{array}$ & $\begin{array}{l}\text { (4) } \\
\text { Loans }\end{array}$ & $\begin{array}{c}(5) \\
\text { Loans }\end{array}$ & $\begin{array}{c}(6) \\
\text { Loans }\end{array}$ \\
\hline Loans (t-1) & $\begin{array}{l}0.628^{* * *} \\
(0.0881)\end{array}$ & $\begin{array}{l}0.619^{* * *} \\
(0.0885)\end{array}$ & $\begin{array}{l}0.629^{* * *} \\
(0.0890)\end{array}$ & $\begin{array}{l}0.628^{* * *} \\
(0.0886)\end{array}$ & $\begin{array}{l}0.620^{\star * *} \\
(0.0887)\end{array}$ & $\begin{array}{l}0.616^{\star * *} \\
(0.0889)\end{array}$ \\
\hline Capital ratio & $\begin{array}{l}0.543^{\star *} \\
(0.238)\end{array}$ & $\begin{array}{l}0.550^{* *} \\
(0.235)\end{array}$ & $\begin{array}{l}0.609^{\star *} \\
(0.265)\end{array}$ & $\begin{array}{l}0.614^{* *} \\
(0.261)\end{array}$ & $\begin{array}{l}0.611^{\text {** }} \\
(0.258)\end{array}$ & $\begin{array}{l}0.668^{* *} \\
(0.283)\end{array}$ \\
\hline Rating & $\begin{array}{c}-0.00034 \\
(0.00208)\end{array}$ & $\begin{array}{r}-0.00088 \\
(0.00210)\end{array}$ & $\begin{array}{r}-0.00012 \\
(0.00213)\end{array}$ & $\begin{array}{r}-0.00012 \\
(0.00216)\end{array}$ & $\begin{array}{c}-0.000650 \\
(0.00216)\end{array}$ & $\begin{array}{c}-0.000734 \\
(0.00224)\end{array}$ \\
\hline Tot collat & $\begin{array}{c}0.0425^{*} \\
(0.0254)\end{array}$ & $\begin{array}{c}0.0319 \\
(0.0287)\end{array}$ & & $\begin{array}{l}0.0489^{* *} \\
(0.0228)\end{array}$ & $\begin{array}{c}0.0383 \\
(0.0253)\end{array}$ & $\begin{array}{c}0.0182 \\
(0.0341)\end{array}$ \\
\hline Illiq collat & & $\begin{array}{c}0.499^{* * *} \\
(0.156)\end{array}$ & & & $\begin{array}{c}0.459^{* * *} \\
(0.143)\end{array}$ & $\begin{array}{l}0.463^{* \star *} \\
(0.147)\end{array}$ \\
\hline Run & & & $\begin{array}{l}-0.0527 \\
(0.0508)\end{array}$ & $\begin{array}{l}-0.0576 \\
(0.0499)\end{array}$ & $\begin{array}{l}-0.0502 \\
(0.0501)\end{array}$ & $\begin{array}{l}-0.106^{*} \\
(0.0623)\end{array}$ \\
\hline Run $\times$ Tot collat & & & & & & $\begin{array}{l}0.846^{\star *} \\
(0.333)\end{array}$ \\
\hline Run $\times$ Illiq collat & & & & & & $\begin{array}{l}-0.512 \\
(1.302)\end{array}$ \\
\hline Adjusted $R^{2}$ & 0.560 & 0.565 & 0.561 & 0.563 & 0.567 & 0.571 \\
\hline Observations & 4,290 & 4,290 & 4,290 & 4,290 & 4,290 & 4,290 \\
\hline
\end{tabular}

Standard errors in parentheses. All variables at the bank level.

Note: Panel regression with residuals clustered at bank level, time, bank and country-time fixed effects.

${ }^{*} p<0.10,{ }^{* *} p<0.05,{ }^{* * *} p<0.01$. 